\title{
A New Wind Change in Direct Taxation
}

\author{
Irma Mosquera Valderrama*
}

Direct taxation in the EU is like a Darrieus Turbine, relatively good efficiency, but it shows poor reliability, as it depends on external power to start, and it tends to be fatigue-prone due to the wide variation in applied forces during each rotation. ${ }^{1}$

\section{A. Introduction}

The overall aim of this Article is to analyze the influence of current international tax developments in EU direct taxation with a main focus on companies and the challenges that EU Institutions and EU countries face in light of these developments. These international tax developments have been introduced in 2008-after the financial crisis - and they show the change in wind direction for direct taxation. Examples of these developments include the international tax initiatives to promote transparency and exchange of information, to tackle aggressive tax planning by multinationals, and to achieve fair taxation by introducing the EU list of non-cooperative jurisdictions.

In order to provide a critical reflection on the change of direction in direct taxation in the EU, this Article will use the analogy of a Darrieus Turbine. The main reason for this analogy is that the tools to manage this change in wind direction are similar to a Darrieus Turbine, which generates electricity, but it has failures in its design that makes this turbine unreliable. These failures in design are shown in the failure of the EU to generate legitimacy and trust among EU citizens, EU countries, and third, non-EUcountries, in addition to the failure to increase competitiveness of the EU in the global economy.

${ }^{\star}$ Professor Mosquera is an Associate Professor of Tax Law in the Faculty of Law at the University of Leiden in the Netherlands. She is the Principal Investigator for the ERC Grant GLOBTAXGOV Project: A New Model of Global Governance in International Tax Law Making. The writing and research carried out for this Article is the result of the ERC research in the framework of the GLOBTAXGOV Project (2018-2023). This Project investigates international tax law making, including the adoption of OECD and EU standards by twelve countries. See GLOBTAXGov, https://globtaxgov.weblog.leidenuniv.nl/ (last visited Oct. 28, 2019). The GlobTaxGov Project has received funding from the European Research Council (ERC) under the European Union's Seven Framework Programme (FP/2007-2013) (ERC Grant agreement n. 758671).

${ }^{1}$ See Wind turbine, WIKIPEDIA (Jul. 22, 2019), https://en.wikipedia.org/wiki/Wind_turbine; Vertical axis wind turbine, WIKIPEDIA (July. 22, 2019), https://en.wikipedia.org/wiki/Vertical_axis_wind_turbine. See also Low Cycle Fatigye Testing, TEST DEVICES INC., https://www.testdevices.com/spin-testing/low-cycle-fatigue/ (last visited Oct. 28, 2019):

The term "fatigue", as applied to materials and machine components, refers to the generation of cracks at stress levels that can be well below the ultimate strength of the material and even within the elastic range below the yield stress. If undetected, these cracks can lead to failure of the component and damage or destruction of the machine. Fatigue cracking is caused by fluctuating stress levels. It typically occurs at inconsistencies in the material such as pores or impurity inclusions but it can also occur in pristine material. It is also prone to occur a component features that create local "stress risers" such as sharp corners or bolt holes.

(C) The Author(s) 2020. Published by Cambridge University Press on behalf of the German Law Journal. This is an Open Access article, distributed under the terms of the Creative Commons Attribution-NonCommercial-ShareAlike licence (https://creativecommons.org/ licenses/by-nc-sa/4.0/), which permits non-commercial re-use, distribution, and reproduction in any medium, provided the same Creative Commons licence is included and the original work is properly cited. The written permission of Cambridge University Press must be obtained for commercial re-use. 
The main research question addressed in this Article is whether the EU changes in direct taxation are facing the same obstacles of Darrieus Turbines the EU changes in direct taxation facing the obstacles of a Darrieus Turbine and, if so, what can be done to tackle these obstacles?

The structure of this Article is as follows: First, the tax developments since 2008 at the international and the EU level will be presented. Second, the challenges that the EU faces will be addressed. Third, the analogy to the Darrieus Turbine will be presented. Fourth, some conclusions will be provided.

\section{B. Current International Tax Developments}

Since the 2008 financial crisis, direct taxation in the European Union has changed following the international tax initiatives by the OECD and G20 to tackle tax fraud, tax evasion, and aggressive tax planning by multinationals.

Before 2008, changes in the field of direct taxation were constrained by the slow pace of the adoption of directives, mainly due to the unanimity rule and the lack of a clear consensus among EU countries on the content of such directives. For example, the 1990s Directives on Merger Directive (90/434/EEC) and the Parent and Subsidiary Directive (90/435/EEC) took more than thirty years to be approved and have since been amended further.

The financial crisis in the OECD led to political support for the G20 in promoting transparency, exchanging information-first on request and then automatic - and more recently in 2013, introducing a project-the BEPS Project-to tackle profit shifting by multinationals. This BEPS project also resulted in the adoption of 4 Minimum Standards, ${ }^{2}$ ten best practices, and one multilateral instrument to modify bilateral tax treaties. ${ }^{3}$ These initiatives have spread around the world, and - at the time of writing - more than one hundred countries and jurisdictions have committed to or endorsed the Standard on Exchange of Information, including the automatic exchange of financial accounting information and the BEPS 4 Minimum Standards. In addition, eighty-nine countries and jurisdictions - including EU countries—-have signed the multilateral instrumentin force since July $2018 .^{4}$

The EU also wanted to play an important role in these international tax developments, and therefore-at EU level-some of these international tax initiatives, including the BEPS 4 Minimum Standards have been adopted through directives-for example amendments to the Directive on Administrative Cooperation ${ }^{5}$ and the Introduction of Anti-Tax Avoidance Directive (2016/1164 ATAD 1 and its amendment ATAD 2).

In some cases, the EU has gone further than the OECD and G20, for instance by introducing an exit rule in ATAD 1-Article 5-and by introducing some of the BEPS ten best practicesActions 2, 3, and 46 -as requirements for EU companies and Action 2 for companies located in third non-EU countries carrying out operations in the EU, ATAD $2 .^{7}$

\footnotetext{
${ }^{2}$ The BEPS 4 Minimum Standards that should be implemented are countering harmful tax practices and exchange of rulings (Action 5), preventing of treaty abuse (Action 6), reexamining transfer pricing documentation including country by country reporting (Action 13), and enhancing resolution of disputes (Action 14).

${ }^{3}$ BEPS-Actions, OECD, http://www.oecd.org/tax/beps/beps-actions/ (last visited Jul. 22, 2019).

${ }^{4}$ Signatories and Parties to the Multilateral Convention to Implement Tax Treaty Related Measures to Prevent Base Erosion and Profit Shifting, OECD (2019), https://www.oecd.org/tax/treaties/beps-mli-signatories-and-parties.pdf.

${ }^{5}$ Administrative Cooperation in (Direct) Taxation in the EU), EUR. COMMISSION, https://ec.europa.eu/taxation_customs/ business/tax-cooperation-control/administrative-cooperation/enhanced-administrative-cooperation-field-direct-taxation_en (last visited Jul. 22, 2019).

${ }^{6}$ Action 2 refers to neutralizing the effects of hybrid mismatches, Action 3 refers to controlled foreign corporation rules, and Action 4 refers to limitations on interest deductions.

${ }^{7}$ New EU Rules to Eliminate the Main Loopholes Used in Corporate Tax Avoidance Come Into Force on 1 January, European Commission Press Release IP/18/6853 (Dec. 30, 2018), http://europa.eu/rapid/press-release_IP-18-6853_en.htm.
} 
Furthermore, in $2008,{ }^{8}$ the EU decided to introduce the EU Standard of Good Tax Governance that contains transparency, exchange of information, and fair taxation. Since April 2018, this Standard also included the BEPS 4 Minimum Standards. ${ }^{9}$ This Standard is introduced as a condition for EU development aid, trade, or strategic partnership agreements with third countries. The Standard is also applied as a condition for countries not to be included in the EU list of non-cooperative jurisdictions. ${ }^{10}$

Another development-also related to companies-is the State Aid Investigations for tax rulings granted to multinationals by EU countries. These investigations have influenced the way that EU and non-EU companies structure their business within the EU and outside of the EU. One example that can illustrate this influence is the United States' changes in the tax system, for example, its Tax Cuts \& Jobs Act Reform that encourages US multinationals to bring overseas funds back to the United States-the repatriation of profits.

One obstacle in EU decision making is the lack of coordination in the EU on tax initiatives and the different roles played by EU countries. For instance, the change of direction from EU countries in the proposals to tax the digital economy and to introduce a global minimum tax rate serves as an example of this lack of coordination. The first attempt to regulate this digital economy was an EU Commission paper from March 2018. ${ }^{11}$ This attempt was followed by an OECD Public Consultation and Work Program — taking place from February to March of 2019 ${ }^{12}$ — to the G20, France's unilateral Digital Services Tax on July 11, 2019, ${ }^{13}$ and a G7 commitment to OECD work on July $17,2019 .^{14}$

In 2019, the EU Commission decided to open the door to qualified majority voting for matters of direct taxation-COM (2019) 8 final-which, if approved, will substantially change the way that EU rules for direct taxation are being discussed. This change may bring some countriesfor instance, France and Germany-that are very supportive of this proposal to a more powerful role at EU level, since the unanimity will no longer be the obstacle for change. Small countries such as Ireland, Luxembourg, and the Netherlands, are against the qualified majority voting proposal based mainly on the argument of tax sovereignty. ${ }^{15}$

These developments bring several challenges to the role of the EU and EU Institutions in the field of direct taxation and also to the role of EU countries. Therefore, the international tax developments and the changes at the EU level should be analyzed in light of the legitimacy and competitiveness of the EU vis-á-vis both EU countries and third, non-EU countries. In the past, this

\footnotetext{
${ }^{8}$ Council of the European Union Press Release 8850/08 (Presse 113), 2866Th Council Meeting Economic AND FinANCIAL AfFairs, 22-23 (2008), https://www.consilium.europa.eu/ueDocs/cms_Data/docs/pressData/en/ecofin/ 100339.pdf.

${ }^{9}$ Council of the European Union Conclusions FisC 180, ECOFIN 364, Council Conclusions on the EU Standard Provision on Good Governance in Tax Matters for Agreements with Third Countries (2018), http://data.consilium.europa.eu/doc/document/ST-8344-2018-INIT/en/pdf.

${ }^{10}$ Irma Johanna \& Mosquera Valderrama, The EU Standard of Good Governance in Tax Matters for Third (Non-EU) Countries, GLOBTAXGOV BLOG (2019), https://globtaxgov.weblog.leidenuniv.nl/files/2019/04/standard-of-good-governance2019.pdf.

${ }^{11}$ Fair Taxation of the Digital Economy, Eur. Commission, https://ec.europa.eu/taxation_customs/business/company-tax/ fair-taxation-digital-economy_en (last visited Jul. 22, 2019).

${ }^{12}$ OECD/G20, Programme of Work to Develop a Consensus Solution to the Tax Challenges Arising from the Digitalisation of the Economy, http://www.oecd.org/tax/beps/programme-of-work-to-develop-a-consensus-solution-to-the-tax-challengesarising-from-the-digitalisation-of-the-economy.pdf.

${ }^{13}$ France Defiant on Plans to Impose 'Gafa' Tax on Tech Giants, France24 (Jul. 17, 2019), https://www.france24.com/en/ 20190717-france-defiant-plans-impose-gafa-tax-tech-amazon-google-facebook-apple.

${ }^{14}$ G7 Ministers 'Agree in Principle' on Deal Taxing Digital Giants, France24 (Jul. 18, 2019), https://www.france24.com/en/ 20190718-g7-ministers-corporate-digital-tax-gafa-deal-digital-giants.

${ }^{15}$ Jorge Valero, Member States Shield National Vetoes on Tax Matters, Euractive (Feb. 13, 2019), https://www.euractiv. $\mathrm{com} /$ section/economy-jobs/news/member-states-shield-national-vetoes-on-tax-matters/.
} 
legitimacy has been questioned by the United States, regarding the State Aid investigations; ${ }^{16}$ by Ireland, regarding the sovereignty of EU countries in direct taxation, ${ }^{17}$ and by Luxembourg, regarding the lack of certainty in respect of the arm's length principle. ${ }^{18}$ The following section will address some of the questions that need to be considered in the analysis on legitimacy and competitiveness.

\section{Challenges}

The first question that needs to be addressed by EU Institutions and EU countries is, if by going further than BEPS 4 Minimum Standards in ATAD 1 and 2, will the EU competitiveness-of the EU and EU countries-be at risk mainly due to the relocation of companies outside the EU that can also result in losing jobs? Is there a cost benefit analysis to take into account the effectiveness of the ATAD 1 and 2 in achieving their aims - tackle base erosion and profit shifting — and their efficiency in terms of jobs, companies' relocation, and compliance cost? And if not, should these studies be available so that EU countries can assess how the ATAD 1 and 2 will benefit their tax and economic policies?

The second question is - if by introducing qualified majority voting-how will the EU Commission and EU countries ensure that legitimacy in participation and representation in the agenda and decision making will be ensured for all EU countries, big and small? Will the decisions adopted by Germany and France participating in international fora like the OECD, G20, and G7 be adopted directly in the EU? Or will EU Institutions still take into account the needs and problems of small European countries? If one example can illustrate this, it is the concerns from Eastern and Central European countries regarding the challenges for the implementation of the OECD-G2O BEPS Project. ${ }^{19}$

The third question is whether the EU Standard of Good Tax Governance and the EU list of non-cooperative jurisdictions is legitimate for third, non-EU, countries? The EU goes further than the OECD and G20 by introducing in the Standard the requirement for countries to comply-and to receive-a positive assessment of compliance with the BEPS 4 Minimum Standards in the peer review by the OECD. This creates problems in legitimacy because not all third, non-EU, countries are members of the BEPS Inclusive Framework, and, therefore, not all countries have committed to the implementation of the BEPS 4 Minimum Standard. For instance, the Philippines decided not to participate in the BEPS Inclusive Framework, but it may be compelled to adopt the BEPS 4 Minimum Standards if the EU Standard of Good Tax Governance is included in the current trade negotiation between EU-ASEAN countries-Singapore, Malaysia, Vietnam, Thailand, Indonesia and the Philippines. ${ }^{20}$

\footnotetext{
${ }^{16}$ The European Commission's Recent State Aid Investigations of Transfer Pricing Rulings, US TREASURY WHITE PAPER (Aug. 24, 2016). The United States has also appealed in support of Apple against the State Aid investigation by the European Commission. The appeal was based in the economic consequences of the investigations for Apple and the US. This appeal was dismissed by the CJEU. Case C-12/18, United States of America v. Apple Sales International and Others, ECLI:EU: C:2018:330, Judgment of 17 May 2018.

${ }^{17}$ FT September 2, 2016. Ireland to appeal against EU's Apple ruling https://www.ft.com/content/2b8adff6-711f-11e6-a0c91365ce54b926 and speech Irish Prime Minister to the Irish Upper House on 4 October 2016. See also JOE BRENNAN, Getting to the Core of Europe's Case Against Apple and Ireland, IRISH TIMES (Feb. 3, 2017), https://www.irishtimes.com/business/ economy/getting-to-the-core-of-europe-s-case-against-apple-and-ireland-1.2960870.

${ }^{18}$ Communication Ministry of Finance Luxembourg, Dec. 4, 2015. https://mfin.gouvernement.lu/en/actualites/2015/ 04-luxembourg-fiat.html

${ }^{19}$ In October 2017, in a meeting of Eastern and Central European countries, these countries addressed the "lack of capacity in terms of skilled personnel, information technology and financial resources together with timetable constrains, and legal and administrative obstacles to implementation." 3rd Regional Meeting of the Inclusive Framework on BEPS for Eastern European and Central Asia Countries Co-chairs' Statement, OECD AND MEMbers of THE InClusive FramewOrk (Oct.18-20, 2019), http://www.oecd.org/tax/beps/co-chairs-summary-eastern-europe-central-asia-beps-regional-meeting-2017.pdf.

${ }^{20}$ See Johanna \& Valderrama, supra note 10 , at 461.
} 
In addition, while drafting the list, the EU has made its own evaluation that sometimes differs from the OECD list on harmful tax regimes-for instance Curaçao, which was regarded as compliant by the OECD but needed to introduce changes following the ECOFIN Council. ${ }^{21}$ This evaluation goes beyond the BEPS Project and also shows that the EU wants to play an important role in these developments, but this can bring more problems to third, non-EU, countriesincluding developing countries - that will need to comply not only with the OECD-G20, but also with the EU requirements. Despite the technical assistance given by the EU Commission mainly through EU Development Cooperation, this aid is not enough for third, non-EU, developing countries. It requires coordination in the evaluation of countries by the OECD and the EU.

Regarding EU countries, civil society also calls for the application of the EU list of noncooperative jurisdictions to EU countries ${ }^{22}$. This requirement has been done at the EU Parliament level-motion by Paul Tang ${ }^{23}$ — but not by the EU Commission or the Code of Conduct group. Therefore, to address the concerns of legitimacy, it is important to find out what has been done in EU countries to address fair taxation in the EU.

These challenges need to be addressed by EU Institutions, EU countries, businesses, business associations, and researchers for the well-functioning of the EU as a supranational organization. ${ }^{24}$ If the EU wants third, non-EU, countries-including developed and developing countries-to comply with the Standard of Good Tax Governance, including the standard of fair taxation in the EU, then the concerns of third, non-EU, countries should be addressed. Therefore, in order to enhance legitimacy and trust, the design of direct taxation in the EU should take into account EU institutions and EU countries vis-à-vis EU citizens and third, non-EU, countries.

\section{The Darrieus Turbine}

The international tax developments explained in Section B show the change in wind direction in respect of direct taxation at the EU level since the 2008 financial crisis. The tools to manage this change in wind direction, however, may seem like those of a Darrieus Turbine, which generates electricity, but has failures in its design that make this turbine unreliable. The Darrieus Turbine "is a type of vertical axis wind turbine used to generate electricity from the energy carried in the wind." 25 Because of the design of the turbine, it is difficult to protect it "from extreme wind conditions and in making it self-starting." 26

To consider the analogy between the tax initiatives in direct taxation at the EU level and the Darrieus Turbine, several elements need to be taken into account by EU Institutions and EU countries. The first element is that, in general, this turbine - as in direct taxation-has a relatively good efficiency. For instance, this is the case for introducing Anti-Tax Avoidance Directive (ATAD 1 and 2) and the changes to the Directive in Administrative Cooperation. These instruments are applicable not only to EU countries, but also for third, non-EU, countries. As in the Darrieus Turbine, however, direct taxation is not protected from extreme wind conditions.

\footnotetext{
${ }^{21}$ General Secretariat of the Council, The EU List of Non-Cooperative Jurisdictions for Tax Purposes-Letters Seeking Commitment on the Replacement By Some Jurisdictions of Harmful Preferential Tax Regimes With Measures of Similar Effect, CouncIL Eur. UnION (Feb. 1, 2019), https://data.consilium.europa.eu/doc/document/ST-5981-2019-INIT/en/pdf.

${ }^{22}$ George Turner, The EU Tax Haven Blacklist-A Toothless Whitewash, Tax Just. NeTwork, (Dec. 8, 2017), https://www. taxjustice.net/2017/12/08/eu-tax-haven-blacklist-toothless-whitewash/.

${ }^{23}$ According to the EU Parliament, seven of the twenty-eight countries facilitate aggressive tax planning. These countries are Belgium, Cyprus, Hungary, Ireland, Luxembourg, Malta, and the Netherlands. See The Netherlands Is a Tax Haven Alongside Ireland, Malta and Cyprus, Say MEPs, DuTCH News (Mar. 27, 2019), https://www.dutchnews.nl/news/2019/03/the-netherlandsis-a-tax-haven-alongside-ireland-malta-and-cyprus-say-meps/.

${ }^{24}$ Some of these challenges have been addressed in The External TAX Strategy of the EU IN a Post-BEPS ENVIRONMENT (Adolfo M. Jiménez ed., 2019).

${ }^{25}$ Darrieus wind turbine, WIKIPEDIA, https://en.wikipedia.org/wiki/Darrieus_wind_turbine (last visited Jul. 22, 2019).

${ }^{26} I d$.
} 
The wind conditions in direct taxation are decided by the OECD, G20, and countries such as France and Germany, which are very active in these organizations and in the EU. These wind conditions also lack coordination. For instance, in the digital economy, there are several multilaterallike the OECD, G20, G7, and the EU—and also unilateral initiatives, like France and Spain, which also create problems for the self-starting of these initiatives within the EU and at international level. Some countries, such as the United States, are considering retaliating, for instance regarding the French digital service tax introduced recently, in July of 2019. ${ }^{27}$ The United States has stated that there will be an enquiry on whether this tax is targeting US multinationals - for example Google, Amazon, Facebook, and Apple — and, if so, if there could be retaliatory tariffs by the United States. ${ }^{28}$

The second element is the introduction of the EU Standard of Good Tax Governance, including the list of non-cooperative jurisdictions, that has shown the poor reliability of these initiatives because civil society and the EU Parliament are questioning EU countries' compliance with the list of non-cooperative jurisdictions. Third, non-EU, countries are also questioning the usefulness of the standard of fair taxation in the EU based in the Code of Conduct of Business Taxation, which is not enforceable within the EU by its own nature. This fact requires further analysis into the value of this Code of Conduct and also on the need for changes to this process on black-listing and negotiations of the Standard by the EU vis-à-vis third, non-EU, countries.

The problems in the design of the Darrieus Turbine make this turbine susceptible to being fatigue-prone due to the wide variation in applied forces during each rotation. This fatigue can result in cracks at stress levels that can lead to failure, damage, or the destruction of this turbine. In taxation, the problems addressed in Section $\mathrm{C}$ above show the wide variation in applied forces and that there are cracks in these initiatives. One example is the questioning of legitimacy, sovereignty, and certainty by EU countries-Ireland and Luxembourg-and third, non-EU, countries - for example the United States-regarding State Aid investigations.

These problems and concerns from EU countries should be addressed, or the result could be failure, damage, or destruction because countries will not commit to these initiatives. Some third, non-EU, countries may decide to comply on paper with these initiatives resulting in mock compliance because the changes will not be enforced in practice.

\section{E. Conclusions}

This Article shows that since the 2008 financial crisis, the EU has changed the wind direction in direct taxation, including amendments to the EU Directives-like the Administrative Cooperation - the introduction of new Directives-ATAD 1 and 2-the Standard of Good Tax Governance, and the publication of the list of non-cooperative jurisdictions.

Nevertheless, as in the Darrieus Turbine, the EU is facing obstacles regarding what makes the changes in the EU susceptible to extreme wind conditions. There are also difficulties in starting up, which depend on external forces resulting in poor reliability and a tendency to be fatigue-prone due to the wide variation in applied forces during each rotation.

Therefore, the EU Institutions and EU countries need to evaluate which changes are needed so that the change of wind direction uses a tool that provides a balance between the need for competitiveness and generating legitimacy and trust for countries and taxpayers. These are the challenges that will need to be carefully addressed by the EU in 2020 and the years to come.

\footnotetext{
${ }^{27}$ France Passes Tax on Tech Giants Despite US Threats, BBC News (Jul. 11, 2019), https://www.bbc.com/news/worldeurope-48947922.

${ }^{28}$ Laurel Wamsle, France Approves Tax On Big Tech, And U.S. Threatens To Retaliate, NPR (July 11, 2019), https://text.npr. org/s.php?sId=740688073.
}

Cite this article: Valderrama IM (2020). A New Wind Change in Direct Taxation. German Law Journal 21, 90-95. https:// doi.org/10.1017/glj.2019.102 